\title{
Assessing the potential soil acidification risk under dryland agriculture in the Mlondozi district in the Mpumalanga Province of South Africa
}

\author{
H.G. Jansen van Rensburg ${ }^{1 *}$, A.S. Claassens ${ }^{1}$, D.J. Beukes ${ }^{2}$, H.L. Weepener ${ }^{2}$ \& P.J. Beukes ${ }^{2}$ \\ ${ }^{1}$ Department of Plant Production and Soil Science, University of Pretoria, Pretoria 0002, South Africa \\ ${ }^{2}$ ARC-Institute for Soil, Climate and Water, Private Bag X79, Pretoria 0001, South Africa
}

Accepted 8 September 2009

\begin{abstract}
The farming community in the Mlondozi district in the Mpumalanga Province of South Africa has been part of a government liming intervention with the objective to ameliorate the serious soil acidity problem in the district. The current study was undertaken in order to evaluate the impact of the liming intervention and the risk of reacidification of the soil due to natural and agricultural activities. Acid production in the $0-250 \mathrm{~mm}$ depth varied from a measured 0.21 to 10.31 (mean $3.70 \mathrm{kmol} \mathrm{H}^{+}$ha $^{-1}$ year ${ }^{-1}$ ) in crop production sites. Approximately $190 \mathrm{~kg}$ lime $\mathrm{ha}^{-1} \mathrm{yr}^{-1}$ is required to maintain current soil $\mathrm{pH}$ levels under crop production. The rate of $\mathrm{pH}$ decline for the top 0-250 mm depth was between 0.051 and 0.918 (mean 0.237 ) $\mathrm{pH}_{\text {units year }}{ }^{-1}$. In the absence of remedial lime applications, $\mathrm{pH}\left(\mathrm{H}_{2} \mathrm{O}\right)$ values in most of the area are projected to decrease to the critical value of 5.68 or lower within 4 years. The upper and lower critical $\mathrm{pH}\left(\mathrm{H}_{2} \mathrm{O}\right)$ were found to be between ca. 5.73 and 5.68. Below the lower critical value a reduction in crop production can be expected and above the upper critical value, accelerated acidification takes place. Soils with an extractable Al and acidity of $<0.180$ and $<0.253 \mathrm{cmol}^{(+)} \mathrm{kg}^{-1}$ soil, respectively, a clay content of $26 \%$, and an ECEC value of $3.29 \mathrm{cmol}^{(+)} \mathrm{kg} \mathrm{soil}^{-1}$, or high initial soil pH values, are more at risk to accelerated acidification than soils with lower extractable Al and acidity, higher clay contents and higher ECEC values.
\end{abstract}

Keywords: Acidification rates, acid production loads, buffer capacity, lime requirement

*To whom correspondence should be addressed (E-mail: Hesterjvr@gmail.com)

\section{Introduction}

High soil acidity and Al saturation are two of the major factors responsible for yield reduction and growth of many crops in the Mlondozi district of Mpumalanga Province, South Africa. Highly weathered acid soils have been formed under the natural processes of weathering and acidification under high rainfall conditions. However, further acidification due to bases removed by product removal or movement of cations associated with nitrate production may intensify the soil acidity problem. Although the rate of these acidifying processes is slow under natural conditions, agricultural production systems undergo accelerated soil acidification as a result of anthropogenic inputs and outputs (Helyar, 1976; Helyar \& Porter, 1989; Sumner \& Noble, 2003). The factors that contribute to soil acidification include the initial soil $\mathrm{pH}$, soil buffering capacity, and the acidification rate (Hill, 2003). In soil acidification risk assessment, as with most agricultural risk assessments, a "problem" occurs when productivity, or the sustainability of productivity, is affected. Identifying areas that are at high risk of soil acidification is achieved through determining the number of years until a critical $\mathrm{pH}$ is reached, given the value of each of the contributing risk factors at a geographical location within the study area (Hill, 2003). From a strategic perspective, quantification of acid production rates under various agronomic production systems can assist producers, extension officers, and policy makers in making decisions towards preventing acidification and the long-term impact of a production system.

The current study was undertaken to determine the risk of soil acidification for various land uses in the Mlondozi district. Soil acidity indices, buffer capacity and soil acidification rates were determined for soils under crop production and natural rangeland used for cattle grazing over a period of
6 years. Furthermore, risk maps and management tools were developed for land users and extension personnel to manage soil acidification in a resource-poor farming area at Mlondozi.

\section{Material and methods}

\section{Study area}

The Mlondozi district is situated between $26^{\circ} 05^{\prime} \mathrm{S}-26^{\circ} 30^{\prime}$ $\mathrm{S}$, and $30^{\circ} 44^{\prime} \mathrm{E}-31^{\circ} 00^{\prime} \mathrm{E}$ and occupies a total area of 54000 ha (Figure 1). This district is extremely hilly with altitudes varying from 1700 m.a.s.l. in the north, dropping to 1300 m.a.s.l. centrally and rising to 1580 m.a.s.l in the south. The long-term mean annual rainfall for the study area ranges between 893 to $992 \mathrm{~mm}$ from north to south. Monthly average daily temperature ranges from $10.2^{\circ} \mathrm{C}$ for the coldest month to $18.9^{\circ} \mathrm{C}$ for the hottest month. Historically the area was primarily used for seasonal grazing because of the climatic unsuitability for crop farming. The acid soils developed on quartz monzonite of the Mpuluzi Granite formation and the predominant clay mineral in the study area is kaolinite. Because kaolinitic clays have a relatively low CEC and consequently a low buffer capacity, most of the district is at high risk of soil acidification.

\section{Soil sampling and analysis}

Representative soil samples were collected from two land uses, namely natural rangeland (natural grazing; 23 samples, ca. 50000 ha)) and dryland crop production (77 samples, $c a$. 4000 ha). Figure 1 indicates the spatial distribution of sample points. The sampled soils represented the most dominant soil forms (Soil Classification Working Group, 1991), namely Magwa and Clovelly, with Inanda and Hutton soil forms sub- 
dominant. Topsoil samples $(0-250 \mathrm{~mm})$ were air-dried and ground to pass through a $2 \mathrm{~mm}$ sieve. A particle size analysis was performed on the $<2 \mathrm{~mm}$ soil fraction using the pipette method. Exchangeable cations, cation exchange capacity, soil organic carbon, extractable acidity and aluminium (Al), $\mathrm{pH}$ $\left(\mathrm{H}_{2} \mathrm{O}\right)$ and $(\mathrm{KCl})$, and free oxides of iron $(\mathrm{Fe}), \mathrm{Al}$ and manganese $(\mathrm{Mn})$ were determined according the procedures of The Non-Affiliated Soil Analysis Work Committee (1990). Effective cation exchange capacity (ECEC) was determined as the sum of exchangeable cations $\left(\mathrm{Al}^{3+}+\mathrm{Ca}^{2+}+\mathrm{Mg}^{2+}+\mathrm{K}^{+}+\right.$ $\mathrm{Na}^{+}$) (Sumner and Noble, 2003), The double buffer SMP method of McLean et al. (1978) was used to determine the lime requirement of the soils.

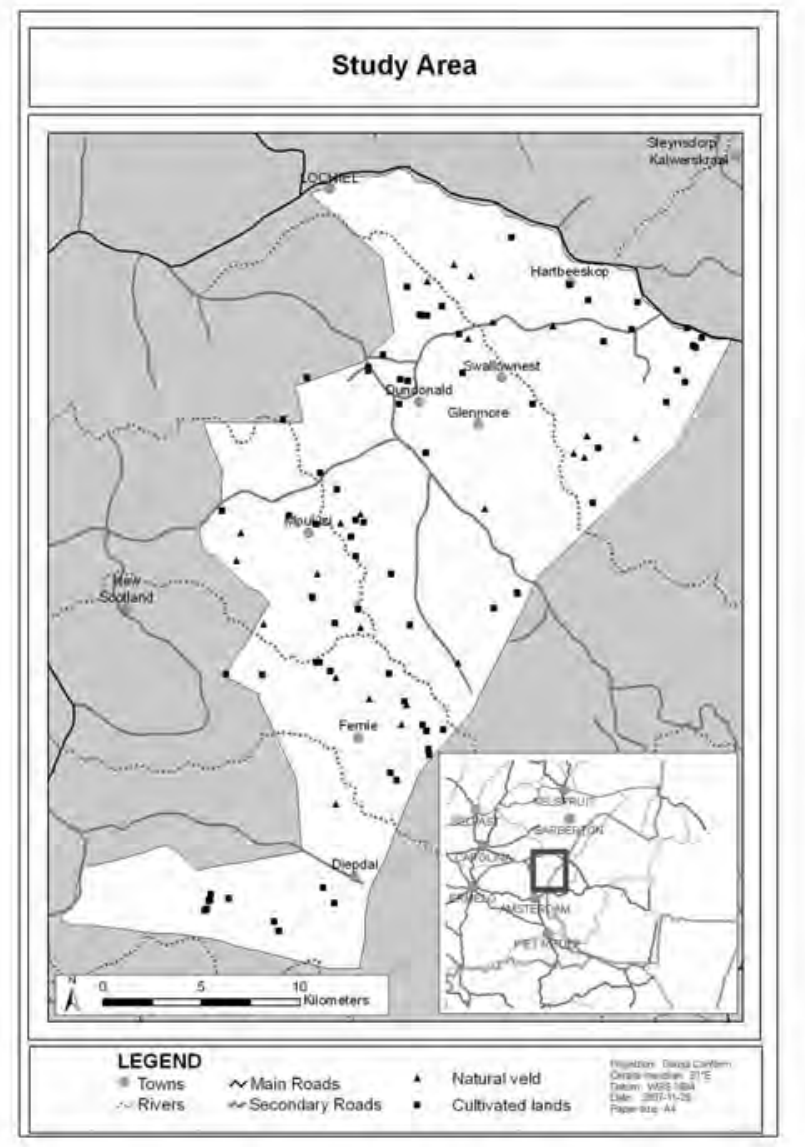

Figure 1 Location of study area and spatial distribution of sample points.

\section{Soil buffer capacity (BC)}

Potentiometric titrations (Ponizovskiy \& Pampura, 1993) were performed on samples that were equilibrated overnight with $1 \mathrm{M} \mathrm{KCl}$. A $50 \mathrm{~g}$ soil sample was suspended in $100 \mathrm{ml} 1$ $\mathrm{M} \mathrm{KCl}$, stirred and left overnight. The suspension was titrated with $0.05 \mathrm{M} \mathrm{NaOH}$ whilst being stirred on a Metrohm potentiograph to a $\mathrm{pH}$ of 8.5 . The titration rate was $0.667 \mathrm{ml} \mathrm{min}^{-1}$. For each soil a linear regression function was fitted to the relationship between $0.05 \mathrm{M} \mathrm{NaOH}$ added and the soil. Equation 1, adapted from Bache (1988), was used to calculate soil $\mathrm{BC}$.
Soil BC $\left[\left(\mathrm{cmol}\left(\mathrm{H}^{+}\right) \mathrm{kg}^{-1}\right.\right.$ soil $\mathrm{pH}$ unit $\left.\left.{ }^{-1}\right)\right]=\Delta\left(\mathrm{OH}^{-}\right) / \Delta \mathrm{pH}$

where $\Delta \mathrm{pH}$ is the change in $\mathrm{pH}$ ( $\mathrm{pH}$ unit) due to the addition of $\mathrm{OH}^{-}\left(\mathrm{cmol}(+) \mathrm{kg} \mathrm{soil}^{-1}\right)$ as $\mathrm{NaOH}$.

The soil BC calculated in Equation 1 was converted to $\left(\mathrm{kmol} \mathrm{H}^{+}\left(\mathrm{ha}_{250 \mathrm{~mm}}\right)^{-1}(\mathrm{pH} \text { unit })^{-1}\right)$ using an average soil bulk density of $1300 \mathrm{~kg} \mathrm{~m}^{-3}$ using Equation 2 as suggested by Singh et al.(2003):

Soil BC $\left[\left(\mathrm{kmol} \mathrm{H}^{+}\left(\mathrm{ha}_{250 \mathrm{~mm}}\right)^{-1}(\mathrm{pH} \mathrm{unit})^{-1}\right)\right]=(\mathrm{BC} \times \mathrm{V} \times \mathrm{BD}) /$ 100000

where $\mathrm{V}$ is volume of soil layer $\left(\mathrm{m}^{3} \mathrm{ha}^{-1}\right)$ to a depth of 250 $\mathrm{mm}$; BD is bulk density $\left(\mathrm{kg} \mathrm{m}^{-3}\right)$ and 100000 to convert cmol $\left(\mathrm{H}^{+}\right)$to $\mathrm{kmol}\left(\mathrm{H}^{+}\right)$.

\section{Acid production loads (APL), acidification rates and maintenance liming}

The acid production load $\left(\mathrm{kmol} \mathrm{H}^{+}\left(\mathrm{ha}_{250 \mathrm{~mm}}\right)^{-1}\right.$ (year) ${ }^{-1}$ ) was calculated with Equation 3 as described by Helyar and Porter (1989):

$\mathrm{APL}=(\Delta \mathrm{pH} / \Delta \mathrm{t}) \times$ soil BC

where $\Delta \mathrm{pH} / \Delta \mathrm{t}$ is the rate of $\mathrm{pH}$ decline ( $\mathrm{pH}$ unit year $\left.{ }^{-1}\right)$.

Estimates of soil acidification rate were calculated as follows:

The decrease in soil $\mathrm{pH}$ in one year $\left(\mathrm{pH}\right.$ year $\left.{ }^{-1}\right)$ was calculated with Equation 4 as reported by Singh et al. (2003), using the APL and soil BC:

$\Delta \mathrm{pH}$ units year ${ }^{-1}=\mathrm{APL} /$ soil BC

The number of years required for a soil to reach a critical $\mathrm{pH}$ value where production losses are likely to occur was calculated as expressed by Hill (2003) in Equation 5:

Time $($ years $)=\left[\left(\mathrm{pH}_{(\text {current })}\right)^{-} \mathrm{pH}_{(\text {critical })}\right) \times($ soil BC $\left.)\right] / A P L$

where $\mathrm{pH}_{\text {(current) }}$ is the current $\mathrm{pH}, \mathrm{pH}_{\text {(critical) }}$ is the critical $\mathrm{pH}$.

Maintenance liming was determined from the annual APL for the top $250 \mathrm{~mm}$ soil. This was achieved using the assumption that 1 mole of $\mathrm{CaCO}_{3}$ neutralizes 2 moles of $\mathrm{H}^{+}$in the soil (Ridley et al., 1990; Dolling et al., 1994).

\section{Spatial interpolation of soil properties and acidification risk}

ArcGIS 9 (ESRI, 2006) was used to interpolate map surfaces for selected soil properties such as $\mathrm{pH}\left(\mathrm{H}_{2} \mathrm{O}\right)$, soil buffer capacity and lime requirement from 100 field sample points using the Inverse Distance Weighting interpolation method. Since acidification risk is strongly dependent on land use, cultivated fields were separated from natural veld by digitizing cultivated land from Spot5 imagery with a $10 \mathrm{~m}$ pixel size. The cultivated fields were then interpolated using inverse distance weighting in ArcGIS 9.2 (ESRI, 2006). In addition, the risk of $\mathrm{pH}$ decreasing below the critical $\mathrm{pH}$ value was evaluated by using Equation 5. Three risk classes were identified: class 1 (high-risk areas with $\mathrm{pH}$ values lower than critical $\mathrm{pH}$ 
values; class 2 (moderate-risk areas expected to acidify to the critical pH in less than 5 years); and class 3 (low-risk area not expected to acidify to the critical $\mathrm{pH}$ within 5 years). The risk evaluation was carried out using inverse distance weighting in ArcGIS 9.2 (ESRI, 2006).

\section{Statistical analysis}

Data was analyzed using Genstat (2003). Pearson's correlations were calculated between all variates measured. Forward Selection Stepwise Regression was used to identify those soil parameters most responsible for describing the variation found in soil BC measurements and lime requirement. Critical values of properties were determined by the broken-stick analysis procedure (Genstat, 2003) where two straight line segments were statistically fitted through datasets that exhibited two distinct populations with linear relationships per population. Where datasets exhibited a non-linear continuum, the Cate-Nelson procedure (Cate \& Nelson, 1971) was used to determine the critical level of the $x$ variable.

\section{Results and discussion}

\section{General and spatial soil characteristics}

Table 1 indicates selected soil chemical and physical properties of the main land uses, namely crop production and natural rangeland. In general, soils from both land uses were acidic, with mean $\mathrm{pH}\left(\mathrm{H}_{2} \mathrm{O}\right)$ values of 5.53 and 5.37 for crop and rangeland soils, respectively. Soils were medium to heavy textured (sandy loam to clay soil texture classes), with medium (1.13\%) to high $(9.14 \%)$ organic C content (mean C values of 2.44 and $2.10 \%$ for crop and rangeland soils, respectively; Table 1).

Table 1 Selected soil physical and chemical topsoil $(0-250 \mathrm{~mm})$ properties for the two dominant land uses in the Mlondozi district

\begin{tabular}{|c|c|c|c|c|c|c|}
\hline \multirow[t]{3}{*}{ Soil property } & \multicolumn{6}{|c|}{ Land use } \\
\hline & \multicolumn{3}{|c|}{ Crop production } & \multicolumn{3}{|c|}{ Natural rangeland } \\
\hline & Range & Mean & Median & Range & Mean & Median \\
\hline $\mathrm{pH}\left(\mathrm{H}_{2} \mathrm{O}\right)$ & $4.60-7.54$ & 5.53 & 5.46 & $4.69-6.18$ & 5.37 & 5.30 \\
\hline $\mathrm{pH}(\mathrm{KCl})$ & $3.72-6.42$ & 4.31 & 4.16 & $3.87-5.24$ & 4.11 & 4.07 \\
\hline Organic C (\%) & $1.14-9.14$ & 2.44 & 2.30 & $1.13-3.18$ & 2.10 & 2.03 \\
\hline Clay (\%) & $19-52$ & 34 & 34 & $8-48$ & 31 & 30 \\
\hline $\mathrm{CEC}\left(\mathrm{cmol}(+) \mathrm{kg}^{-1}\right)$ & $3.34-14.09$ & 7.18 & 6.83 & $3.59-11.73$ & 7.79 & 6.79 \\
\hline $\operatorname{ECEC}\left(\mathrm{cmol}(+) \mathrm{kg}^{-1}\right)$ & $0.78-12.72$ & 4.99 & 4.58 & $2.62-10.31$ & 6.00 & 5.31 \\
\hline Extractable acidity $\left(\mathrm{cmol}(+) \mathrm{kg}^{-1}\right)$ & $0-2.61$ & 0.60 & 0.42 & $0.05-1.50$ & 0.68 & 0.56 \\
\hline Extractable $\mathrm{Al}\left(\mathrm{cmol}(+) \mathrm{kg}^{-1}\right)$ & $0-1.87$ & 0.45 & 0.31 & $1-1.11$ & 0.44 & 0.39 \\
\hline Acid saturation (\%) & $0-94$ & 28 & 17 & $1-70$ & 34 & 37 \\
\hline Soil BC (cmol (+) kg $\left.{ }^{-1} \mathrm{pH}_{\mathrm{unit}^{-1}}\right)$ & $0.22-1.91$ & 0.75 & 0.71 & $0.21-1.54$ & 0.68 & 0.59 \\
\hline CBD-Al (\%) & $0.23-2.43$ & 0.82 & 0.73 & $0.24-1.24$ & 0.57 & 0.45 \\
\hline CBD-Fe (\%) & $0.73-7.11$ & 2.59 & 2.39 & $0.70-4.38$ & 2.21 & 1.51 \\
\hline CBD-Mn (\%) & $0.00-0.02$ & 0.006 & 0.005 & $0.00-0.04$ & 0.007 & 0.003 \\
\hline \multicolumn{7}{|l|}{ Clay mineralogy $(\%)$} \\
\hline - quartz & $0-52$ & 18 & 17 & $7-33$ & 17 & 16 \\
\hline - kaolinite & $32-91$ & 62 & 63 & $42-79$ & 62 & 60 \\
\hline - mica & $0-9$ & 2 & 0 & $0-8$ & 3 & 3 \\
\hline - goethite & $0-30$ & 10 & 11 & $0-22$ & 8 & 9 \\
\hline - gibbsite & $0-44$ & 6 & 0 & $0-16$ & 6 & 5 \\
\hline
\end{tabular}

\section{Soil buffer capacity (BC)}

The soils in the study area were medium to well buffered (Steinke et al, 2004) with soil BC values ranging from 0.124

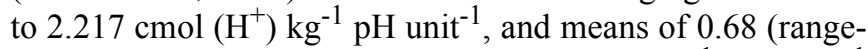

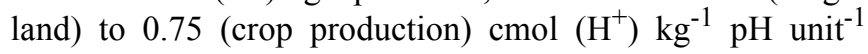
(Table 1). Figure 2 (a) shows a map of the interpolated soil $\mathrm{BC}$ values for the study area. Areas towards the north-east around Hartbeeskop, and south around Fernie and Diepdal, showed the highest resistance to change with soil $\mathrm{BC}$ values greater than $0.9 \mathrm{cmol}^{\left(\mathrm{H}^{+}\right) \mathrm{kg}^{-1} \mathrm{pH} \text { unit }}{ }^{-1}$.
Forward stepwise multiple linear regression analyses indicated that extractable Al, CBD-Fe accounted for $88.4 \%$ for the variation in soil $\mathrm{BC}$ (Table 2 ). The relationship is given by Equation 6.

Soil $\mathrm{BC}=0.842+0.653(\mathrm{Al})+0.109(\log \mathrm{BD}-\mathrm{Fe})$

Where $\mathrm{Al}$ is extractable $\mathrm{Al}\left(\mathrm{cmol}(+) \mathrm{kg}^{-1}\right), \log _{\mathrm{e}} \mathrm{CBD}-\mathrm{Fe}(\%)$. 

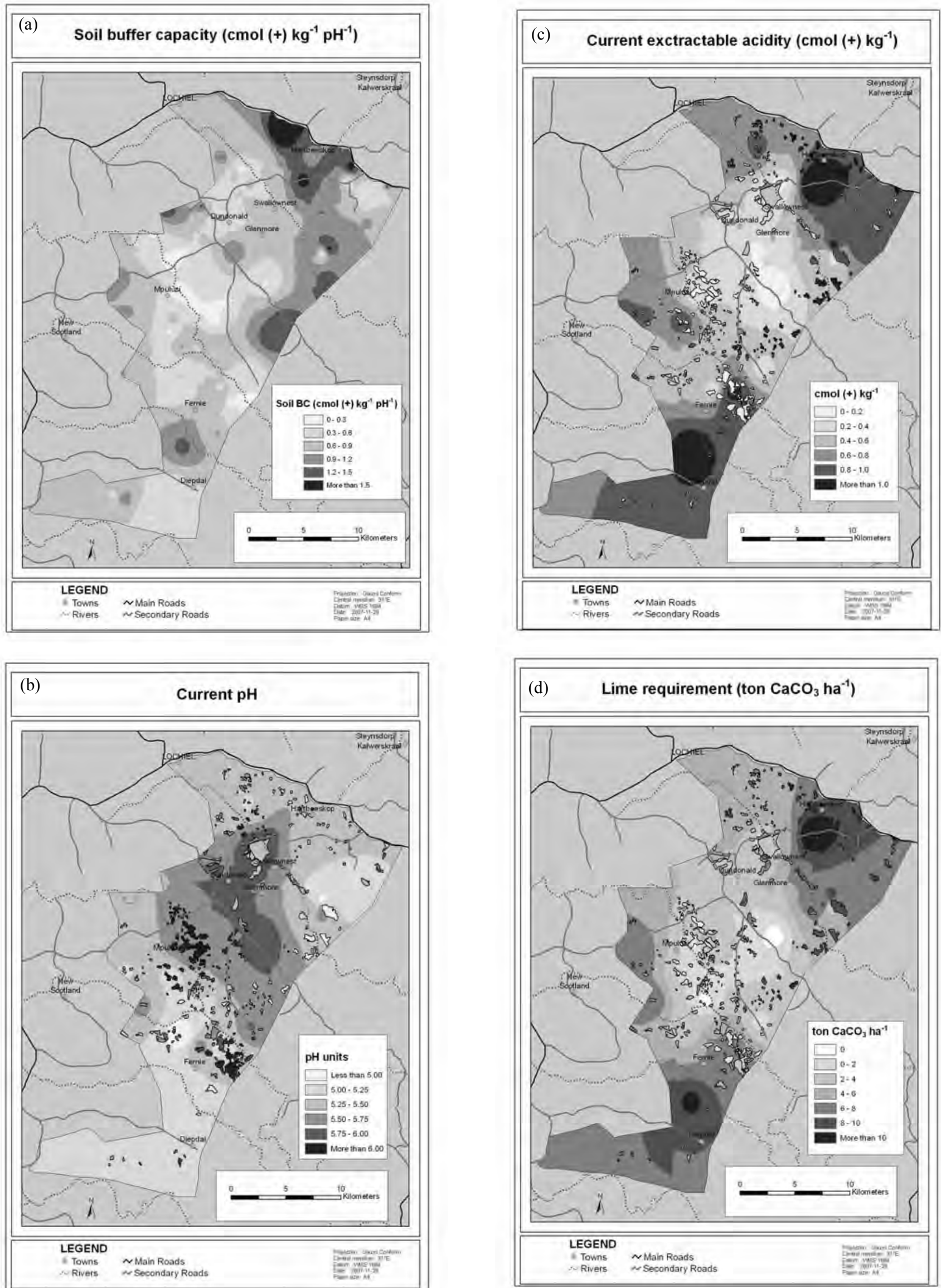

Figure 2 Interpolated maps (1:200 000) of (a) soil BC values, (b) current $\mathrm{pH}\left(\mathrm{H}_{2} \mathrm{O}\right)$, (c) extractable acidity $\left(\mathrm{cmol}^{(+)} \mathrm{kg}^{-1}\right)$ values and (d) lime requirement (ton $\mathrm{CaCO}_{3} \mathrm{ha}^{-1}$ ) from current $\mathrm{pH}\left(\mathrm{H}_{2} \mathrm{O}\right)$ to $\mathrm{pH}\left(\mathrm{H}_{2} \mathrm{O}\right) 6.0$ for the topsoil $(0-250 \mathrm{~mm})$ in the Mlondozi district. 
Table 2 Summary of the forward stepwise regression analysis for soil buffer capacity (soil BC) and lime requirement (LR)

\begin{tabular}{llcc}
\hline \multicolumn{1}{c}{ Independent variable } & \multicolumn{1}{c}{ Dependent variable } & Variance accounted for (\%) & F \\
\hline Soil BC & Extractable Al & 80.1 & $0.187^{* * *}$ \\
& + Fe-CBD & 88.4 & $0.143^{* * *}$ \\
\hline LR & Extractable Al & 57.6 & $2.00^{* * *}$ \\
& + (clay/(organic C x clay)) & 78.2 & $1.44^{* * *}$ \\
& + (organic C/clay) & 84.6 & $1.21^{* *}$ \\
& $+\mathrm{pH}\left(\mathrm{H}_{2} \mathrm{O}\right)$ & 87.0 & $1.11^{*}$ \\
\hline
\end{tabular}

*** $\mathrm{P}<0.001, * * \mathrm{P}<0.01, * \mathrm{P}<0.05$

Figure 3 shows a strong relationship $\left(\mathrm{R}^{2}=0.92\right)$ between soil $\mathrm{BC}$, determined by potentionmetric titrations, and predicted soil $\mathrm{BC}$ values determined from Equation 6. The prediction of soil $B C$ values was best at a measured soil $B C$ value of 0.37 cmol $\left(\mathrm{H}^{+}\right) \mathrm{kg}^{-1} \mathrm{pH}$ unit ${ }^{-1}$. A slight over estimation of soil BC was detected below this value and an under estimation of soil $\mathrm{BC}$ above this value.

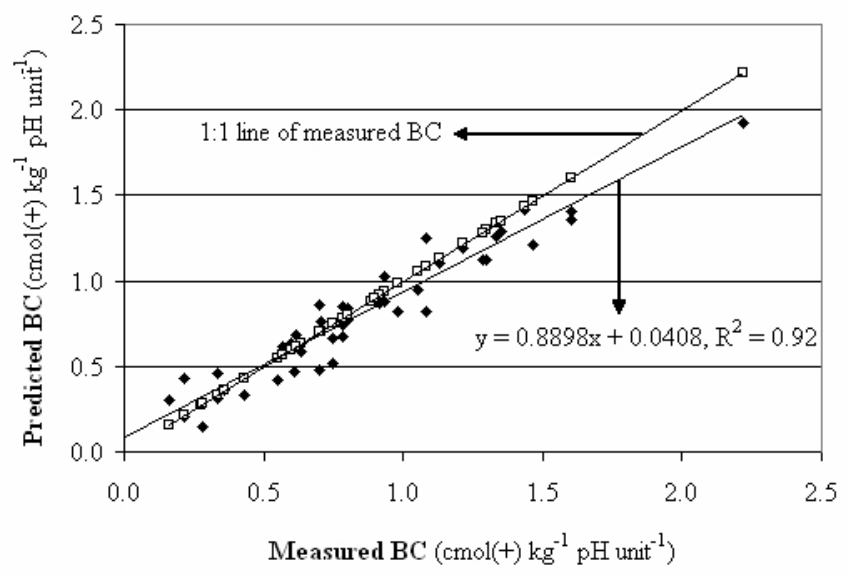

Figure 3 Relationship between measured soil BC determined by potentiometric titrations and predicted soil $\mathrm{BC}$ according to Equation 6.

\section{Critical soil acidity indices}

The relationships between $\mathrm{pH}$ and extractable acidity $(\mathrm{Al}+$ $\mathrm{H})$, and $\mathrm{Al}$ were used to assess the critical $\mathrm{pH}$ values where $(\mathrm{Al}+\mathrm{H})$ and Al-toxicity is likely to be a problem. Linear components of extractable $(\mathrm{Al}+\mathrm{H}), \mathrm{Al}$ and $\mathrm{pH}$ relationships for all the soils were defined by broken-stick techniques. Figure 4 indicates that intercepts for the two lines occurred at $\mathrm{pH}$ $\left(\mathrm{H}_{2} \mathrm{O}\right)=5.68$ for extractable $(\mathrm{Al}+\mathrm{H})$ and extractable $\mathrm{Al}$.

At $\mathrm{pH}\left(\mathrm{H}_{2} \mathrm{O}\right)$ of 5.68, extractable $(\mathrm{Al}+\mathrm{H})$ values of 0.25 cmol $(+) \mathrm{kg}^{-1}$ and extractable $\mathrm{Al}$ of $0.17 \mathrm{cmol}(+) \mathrm{kg}^{-1}$ was recorded. Above this $\mathrm{pH}$, extractable $\mathrm{Al}$ levels were low and regression slopes approached zero. This observation is consistent with previous observations that extractable Al was essentially eliminated above $\mathrm{pH}\left(\mathrm{H}_{2} \mathrm{O}\right) 5.5$ (Coleman \& Thomas, 1967; Juo, 1977; Farina et al., 1980).
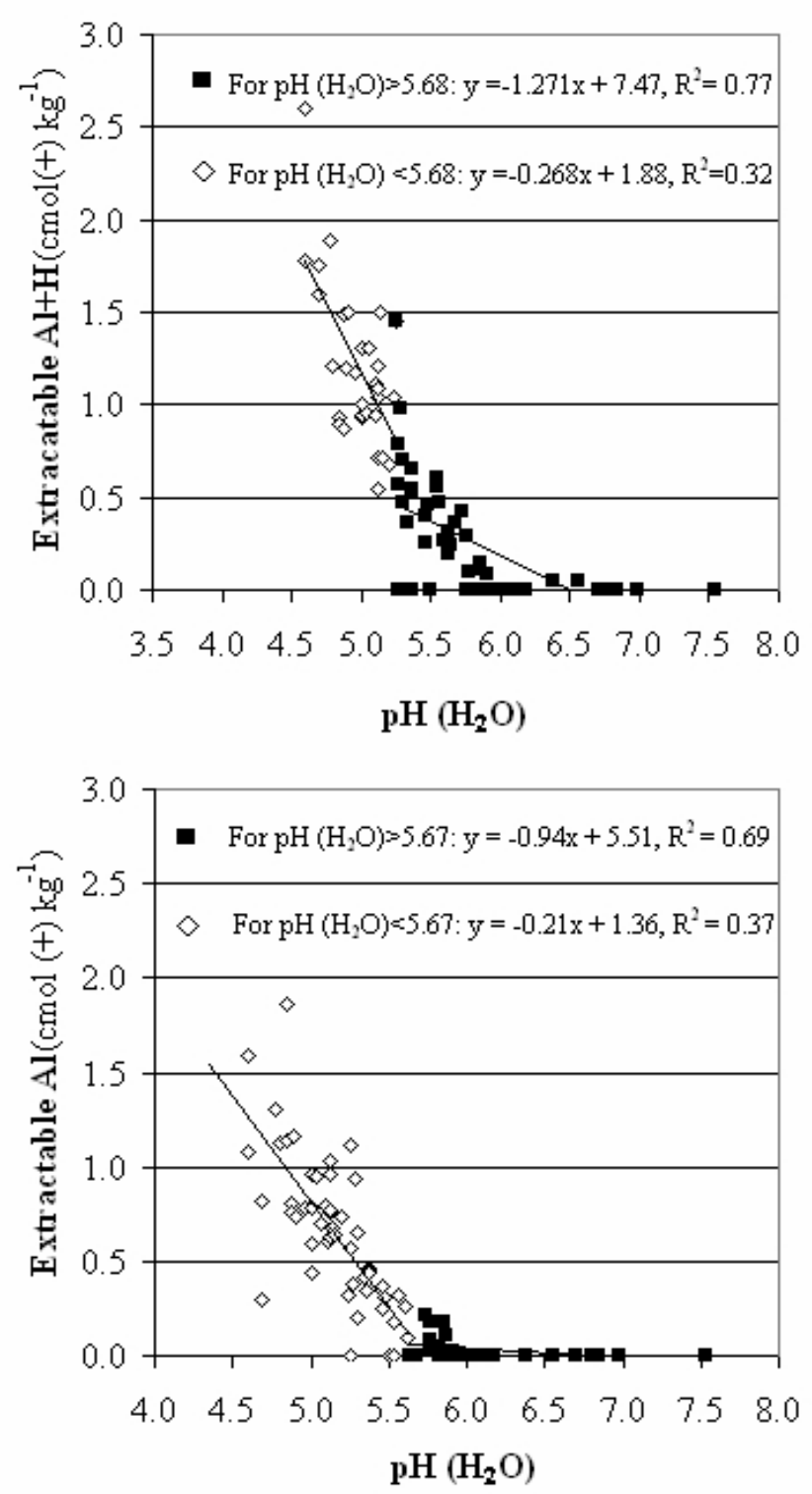

Figure 4 Critical soil $\mathrm{pH}$ values by means of broken-stick analysis between (a) $\mathrm{pH}\left(\mathrm{H}_{2} \mathrm{O}\right)$ and extractable $(\mathrm{Al}+\mathrm{H})$, and (b) $\mathrm{pH}$ $\left(\mathrm{H}_{2} \mathrm{O}\right)$ and extractable $\mathrm{Al}$. 


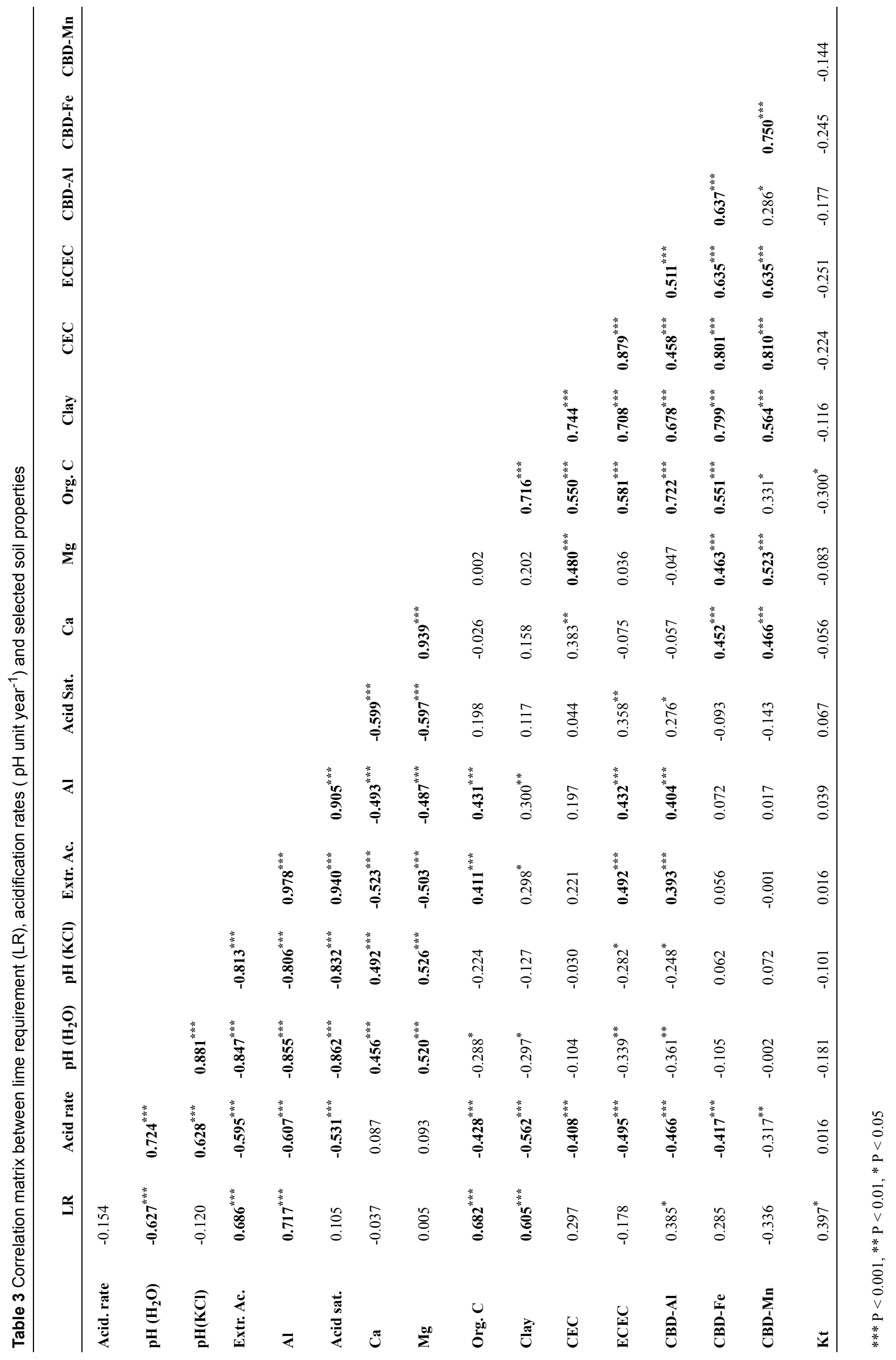


Actual soil acidity indices and lime requirement (LR)

Actual $\mathrm{pH}\left(\mathrm{H}_{2} \mathrm{O}\right)$ and extractable acidity $\left(\mathrm{cmol}(+) \mathrm{kg}^{-1}\right)$ interpolated maps (1:200 000 scale) are shown in Figure $2(\mathrm{~b}$, c). In general, lower soil $\mathrm{pH}$ and higher extractable acidity values for natural veld were recorded in the north-east near Hartbeeskop and to the south of the district around Fernie and Diepdal. There was no clear trend in soil $\mathrm{pH}$ and extractable acidity values for cultivated fields, probably due to the disturbance of the natural soil chemical processes due to cultivation.

The double buffer SMP method (McLean et al., 1978) was used to determine lime requirements to attain a $\mathrm{pH}\left(\mathrm{H}_{2} \mathrm{O}\right)$ of 6.0. Hauman (1981) indicated in a study of 30 topsoil samples of the Highveld region in South Africa that this method most accurately predicted lime requirements.

Table 3 reveals that properties such as extractable acidity $(\mathrm{Al}+\mathrm{H})$ or $\mathrm{Al}$, organic $\mathrm{C}, \mathrm{pH}\left(\mathrm{H}_{2} \mathrm{O}\right)$ and acid saturation are individually highly correlated $(\mathrm{P}<0.001)$ with lime requirement.

Forward selection stepwise regression analysis (Table 2) was used to assess the contribution of various soil parameters to lime requirement as given by Equation 7. The regression model shows that extractable $\mathrm{Al}$ accounts for $57.6 \%$ of the variation in lime requirement. Progressive addition of the variables clay (\%), organic $\mathrm{C}$ and $\mathrm{pH}\left(\mathrm{H}_{2} \mathrm{O}\right)$ increased the explained variation to $87.0 \%$.

$\mathrm{LR}=-1.75+3.07(\mathrm{Al})-17.45($ clay $/(\mathrm{OC} \mathrm{x}$ clay $)-66.7(\mathrm{OC} /$ clay $)$ $+3.45\left(\mathrm{pH}\left(\mathrm{H}_{2} \mathrm{O}\right)\right)$

where $\mathrm{LR}$ is lime requirement (ton pure $\mathrm{CaCO}_{3} \mathrm{ha}^{-1}$ ), $\mathrm{Al}$ is extractable $\mathrm{Al}\left(\mathrm{cmol}(+) \mathrm{kg} \mathrm{soil}^{-1}\right)$, clay is the clay $\%$ and $\mathrm{OC}$ is organic $\mathrm{C}(\%)$. The high coefficient of determination suggests that these relationships would prove to be satisfactory predictors of LR as shown in Figure 5.

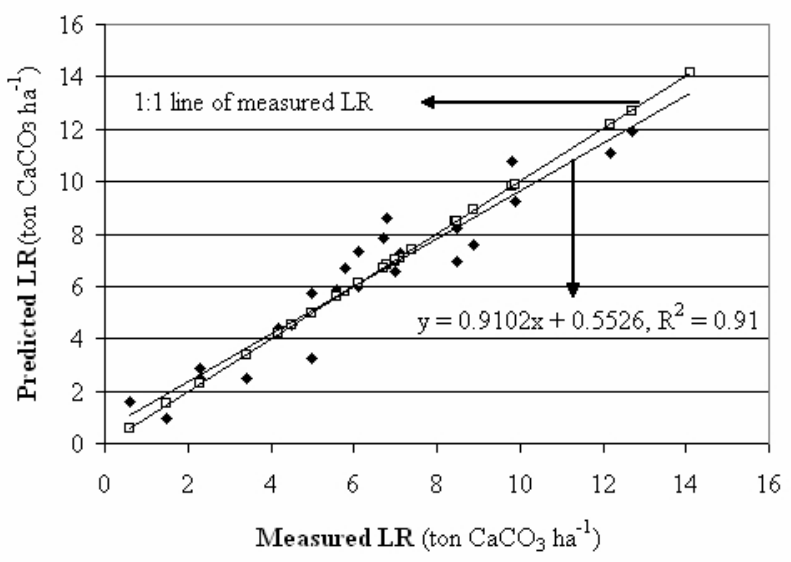

Figure 5 Relationship between measured lime requirement (ton $\mathrm{CaCO}_{3} \mathrm{ha}^{-1}$ ) and predicted lime requirement according to Equation 7.

The prediction of $L R$ values attained maximum accuracy at a measured lime requirement of 6.15 ton $\mathrm{CaCO}_{3} \mathrm{ha}^{-1}$. A slight overestimation of lime requirement was detected below this value and an underestimation of lime requirement above this value. Figure 2 (d) shows a map of the interpolated lime requirement values for the study area. Soils with high lime requirement values corresponded with areas of high soil BC values (compare Figures 2 (a) and 2 (d)).

\section{Acid production load (APL)}

In order to determine APL (using Equation 2), medium-term changes in soil $\mathrm{pH}\left(\mathrm{H}_{2} \mathrm{O}\right)$ values for 35 dryland crop production sites (mainly maize) were used in the study area. APL

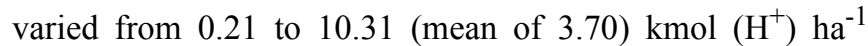
year $^{-1}$, depending on the production system and fertilizer inputs. Therefore, an APL value of 3.70 (mean of measured APLs) for cultivated land was used in the study to simulate acidification rates for the Mlondozi district. The lime required to balance the APL to $250 \mathrm{~mm}$ depth varied between 97 and $527 \mathrm{~kg} \mathrm{CaCO}_{3} \mathrm{ha}^{-1}$ year $^{-1}$, with a mean of $190 \mathrm{~kg} \mathrm{CaCO}_{3} \mathrm{ha}^{-1}$ year ${ }^{-1}$ in the crop production sites. The APLs recorded in the study (mean of $1.39 \mathrm{kmol}^{\left(\mathrm{H}^{+}\right) \mathrm{ha}^{-1} \text { year }}{ }^{-1}$ to a depth of 100 $\mathrm{mm}$ ) were similar to APLs recorded by Helyar et al. (1990) under continuous wheat/fallow rotation to a depth of $100 \mathrm{~mm}$.

\section{Acidification risk assessment}

In order to spatially simulate the decline in soil $\mathrm{pH}\left(\mathrm{H}_{2} \mathrm{O}\right)$ of the topsoil $(0-250 \mathrm{~mm})$ over time, APLs were combined with geostatistics. Interpolated acidification risk maps were created at a 1:200 000 scale using $\mathrm{pH}\left(\mathrm{H}_{2} \mathrm{O}\right)$ per annum, years until the critical $\mathrm{pH}\left(\mathrm{H}_{2} \mathrm{O}\right)$ of 5.68 is reached and a spatial risk classification of the district (Figure 6 (a-c)).

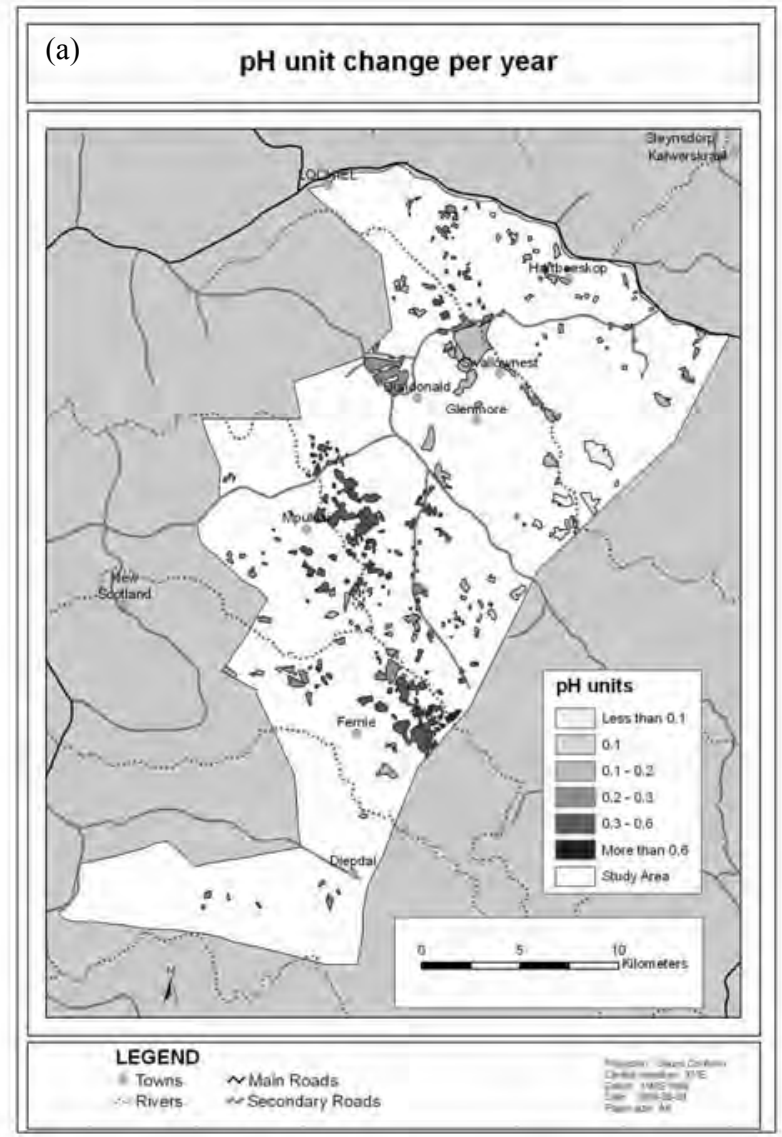



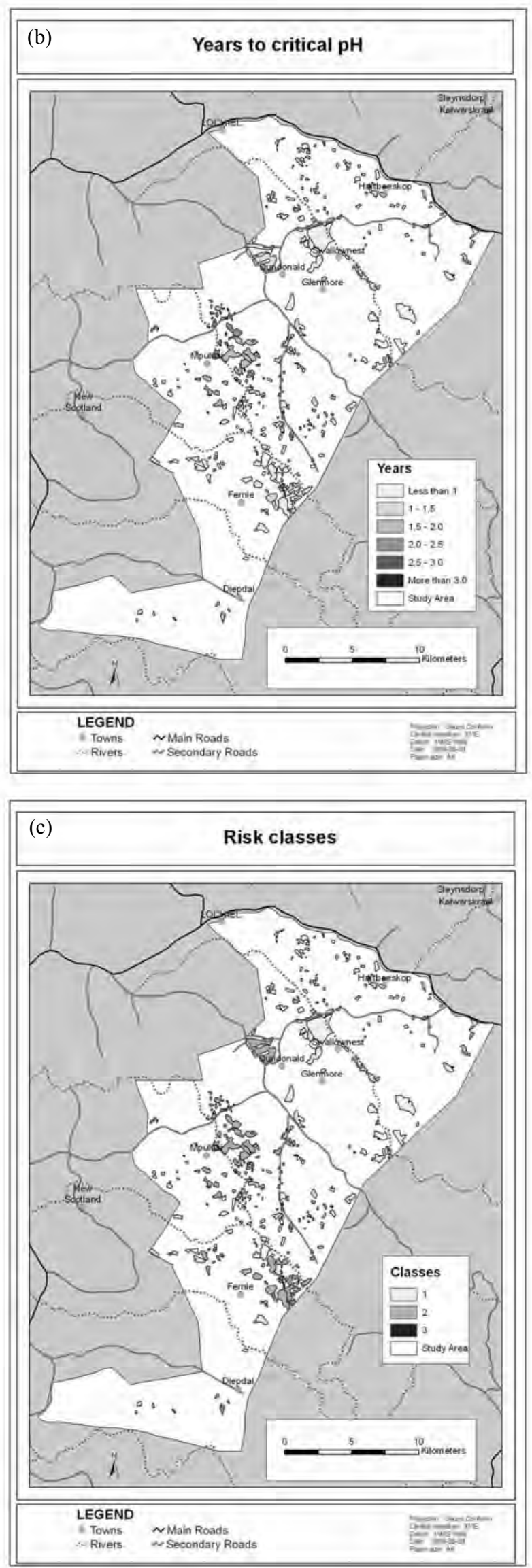

Figure 6 Interpolated maps (1:200 000) of (a) $\mathrm{pH}\left(\mathrm{H}_{2} \mathrm{O}\right)$ change per year, (b) years until critical $\mathrm{pH}\left(\mathrm{H}_{2} \mathrm{O}\right)$ is reached and (c) risk classes for the topsoil $(0-250 \mathrm{~mm})$ in the Mlondozi district.
Figure 6 (a) indicates that the rate of $\mathrm{pH}$ decline for the top $250 \mathrm{~mm}$ soil depth was between 0.051 and 0.918 (mean 0.237 ) units year ${ }^{-1}$, with the fastest rates on the crop production sites in the Mpuluzi and Fernie areas characterized by lower soil BC values. The expected number of years until a given critical $\mathrm{pH}$ is reached (Figure $6(\mathrm{~b})$ ) enables acidification risk predictions (Figure 6 (c)) to be made by identifying the bracket within which the number of years falls (Hill, 2003). Figure 6 (b) shows that within two years the $\mathrm{pH}\left(\mathrm{H}_{2} \mathrm{O}\right)$ of most of the Mlondozi district would decrease to below the critical $\mathrm{pH}$ of 5.68. Results indicate that interventions should focus on cultivated areas in the central parts around Swallownest and Glenmore, the northern parts around Hartbeeskop, the eastern parts, and to the west and north of Fernie (risk class 1) where $\mathrm{pH}\left(\mathrm{H}_{2} \mathrm{O}\right)$ was already lower than the critical $\mathrm{pH}$ (Figure 6 (c)).

\section{Relationship between acidification rate and selected soil properties}

Table 3 shows that several soil properties were highly significantly $(\mathrm{P}<0.001)$ correlated with acidification rate.

Soil $\mathrm{pH}\left(\mathrm{H}_{2} \mathrm{O}\right)$ and $\mathrm{pH}(\mathrm{KCl})$ are individually the best correlated $(r=0.724,0.628)$ with acidification rate, followed by extractable $\mathrm{Al}$ and acidity $(\mathrm{Al}+\mathrm{H})$, clay content, acid saturation and ECEC. Table 3 and Figure 7 show that acidification rate $\left(\mathrm{pH}\right.$ unit year $\left.{ }^{-1}\right)$ was high if the initial soil $\mathrm{pH}\left(\mathrm{H}_{2} \mathrm{O}\right.$ or $\mathrm{KCl})$ was high or extractable $(\mathrm{Al}+\mathrm{H}),(\mathrm{Al})$ or acid saturation were low.

Doerge and Gardner (1985) stated that increased pH values which are the result of lime application, stimulate soil acidification processes and net soil acidification occurs at an accelerated rate. The reasons for the increase in acidification risk with increasing $\mathrm{pH}$ values are due to increased decomposition rates of organic matter, resulting in a release of reduced forms of $\mathrm{N}$ and $\mathrm{S}$. Furthermore, at high $\mathrm{pH}$ values, extractable $\mathrm{Al}$ is essentially eliminated and does not contribute to buffering. And lastly, increase $\mathrm{pH}$ leads to optimal conditions for nitrification (Gasser, 1973; Hoyt \& Henning, 1982; Matzner \& Meiwes, 1994) that resulted in high production of $\mathrm{H}^{+}$. Table 4 and Figure 7 show critical soil parameters where acceleration in acidification could be expected.

Table 4 Non-linear regression analysis between various soil properties and acidification rate.

\begin{tabular}{lccc}
\hline \multicolumn{1}{c}{ Variables } & $\mathbf{R}^{2} \mathbf{( \% )}$ & $\mathbf{F}$ & Critical value \\
\hline Soil $\mathrm{pH}\left(\mathrm{H}_{2} \mathrm{O}\right)$ & 57.72 & $102.39^{* * *}$ & 5.73 \\
Extractable Al & 47.48 & $69.60^{* * *}$ & $0.180 \mathrm{cmol}(+) \mathrm{kg} \mathrm{soil}^{-1}$ \\
Extractable acidity & 47.92 & $70.84^{* * *}$ & $0.253 \mathrm{cmol}(+) \mathrm{kg} \mathrm{soil}^{-1}$ \\
ECEC & 43.63 & $38.06^{* * *}$ & $3.29 \mathrm{cmol}(+) \mathrm{kg} \mathrm{soil}^{-1}$ \\
Clay & 29.20 & $28.45^{* * *}$ & $26.10 \%$ \\
\hline
\end{tabular}

*** $\mathrm{P}<0.001, * * \mathrm{P}<0.01$, and $* \mathrm{P}<0.05$

Figure 7 (a) shows that above a critical $\mathrm{pH}\left(\mathrm{H}_{2} \mathrm{O}\right)$ value of 5.73, acidification rates are accelerated. Critical threshold values for extractable $\mathrm{Al}$ and acidity were recorded as $<0.180$ and $0.253 \mathrm{cmol}^{(+)} \mathrm{kg} \mathrm{soil}^{-1}$ (Table 4). Below these critical values acceleration in acidification could be expected (Figure 7 (c, d)). Table 4 and Figure 7 (e) shows that the acidification rate as affected by ECEC, is the highest when this value drops 
below $3.29 \mathrm{cmol}^{(+)} \mathrm{kg}$ soil $^{-1}$. Table 4 and Figure 7 (f) furthermore shows that, not surprisingly, the acidification risk decreased with an increase in clay content. The smallest change in $\mathrm{pH}$ value over time was recorded at clay content higher than $26.1 \%$.
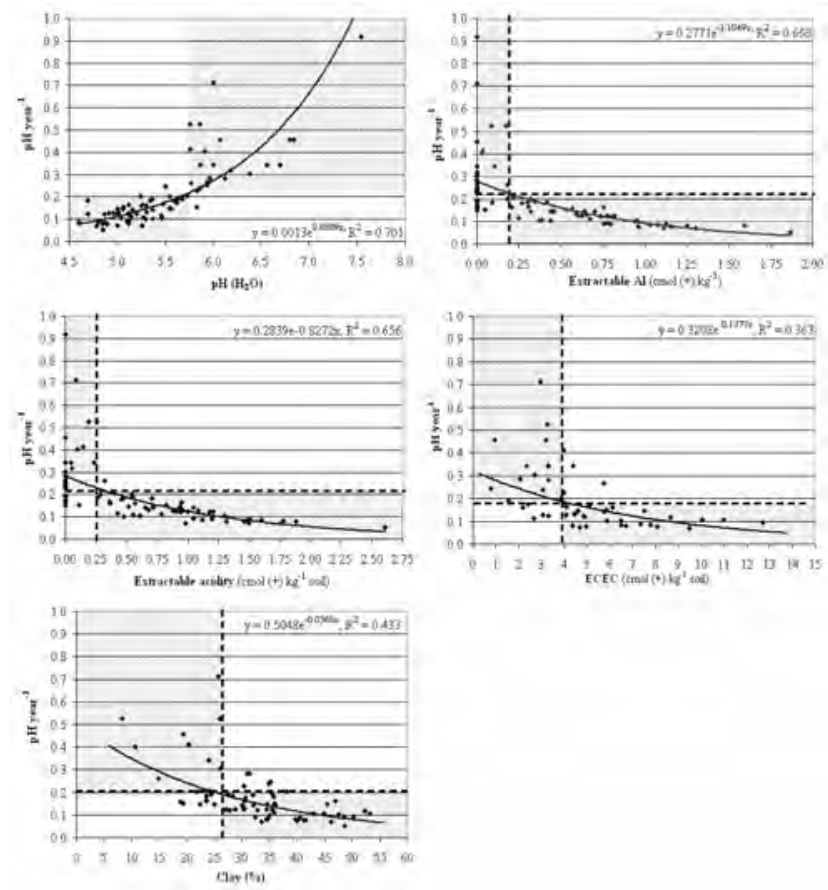

Figure 7 The relationship between acidification rate $\left(\mathrm{pH}\right.$ year $\left.{ }^{-1}\right)$ and (a) soil $\mathrm{pH}\left(\mathrm{H}_{2} \mathrm{O}\right)$, (b) $\mathrm{pH}(\mathrm{KCl})$, (c) extractable $\mathrm{Al}$, (d) extractable acidity, (e) ECEC ( $\mathrm{cmol}(+) \mathrm{kg}^{-1}$ soil) and (f) clay content.

\section{Conclusions and recommendations}

The farming community in the Mlondozi district has to make a living on soil where $\mathrm{pH}(\mathrm{H} 2 \mathrm{O})$ levels show that $40 \%$ of the topsoil has a $\mathrm{pH}$ below a critical value of 5.68 , indicating that a decline in crop growth and yield may be expected. The soil acidification risk techniques used in the study proved to be a valuable tool to assist land users, extension officers, and policy makers in making decisions on the long-term impact of production systems on the resource base. The results furthermore show the need to re-examine current agricultural and intervention strategies in order to reduce the impact of soil acidity and reduce current soil acidification rates. It has been shown in the study that the Mlondozi area (4 000 ha cropland) would require an amount of 760 ton $\mathrm{CaCO}_{3} \mathrm{ha}^{-1}$ year ${ }^{-1}$ to maintain current soil acidification rates in the Mlondozi district. From a strategic perspective, it is recommended that acid production rates and the maintenance liming amounts be quantified in the study area to assist producers, extension officers, and policy makers in making decisions towards preventing acidification and the long-term impact of a production system.

\section{Acknowledgements}

We acknowledge the support given by Mr Leon de Beer and other extension staff of the Mpumalanga Department of Agriculture and Land Affairs. The authors extend their thanks to
Mrs Marie Smith for statistical analyses. Sincere thanks also go to personnel of the ARC-Institute for Soil, Climate and Water for technical assistance, especially Mrs Annari Venter and Mr Michael Kidson. The work was jointly funded by the Agricultural Research Council and the South African National Department of Agriculture.

\section{References}

BACHE, B.W., 1988. Measurements and mechanisms in acid soils. Comm. Soil Sci. Plant Anal., 19, 775-792.

CATE, R.B. \& NELSON, L.A., 1971. A simple statistical procedure for partitioning soil test correlation data into two classes. Soil Sci. Soc. Am. Proc. 35, 658-659.

COLEMAN, N.T. \& THOMAS, G.W., 1967. The basic chemistry of soil acidity, p. 1-42. In: R.W. Pearson \& F. Adams (eds.). Soil Acidity and Liming. Am. Soc. Agron., Madison, Wisc.

DOERGE, T.A. \& GARDNER, E.H., 1985. Reacidification of two lime amended soils in Eastern Oregon. Soil Sci. Soc. Amer. J., 49, 680-685.

DOLLING, P.J., PORTER, W.M. \& ROWLAND, I.C., 1994. Acidification rates in the central wheatbelt of Western Australia. II. On a sandy duplex soil. Austr. J. Experm. Agri., 34, 1165-1172.

ESRI, 2006. ArcGIS 9.2. Environmental Systems Research Institute, Inc. Redlands, CA.

FARINA, M.P.W., SUMNER, M.E., PLANK, C.O. \& LETZCH, W.S., 1980. Exchangeable Aluminium and $\mathrm{pH}$ as Indicators of Lime Requirement for Corn. Soil Sci. Soc. Am. J., 44, 1036-1041.

GASSER, J.K.R., 1973. An assessment of the importance of some factors causing losses of lime from agriculture soils. Exp. Husb., 25, 86-95.

GENSTAT., 2003. GENSTAT 4.23, Reference Manual Laws Agricultural Trust, Rothamsted Experimental Station. Claredon Press, Oxford Science Publications, UK.

HAUMAN, P.E., 1981. A comparison of buffer methods for determining lime requirement of acid soils of the Highveld region. Agrochemophysica 13, 37-41.

HELYAR, K.R., 1976. Nitrogen cycling and soil acidification. $J$. Austr. Inst. Agric. Sci. 42, 217-221.

HELYAR, K.R. \& PORTER, W.M., 1989. Soil acidification, its measurement and the process involved, p. 61-101. In: A.D. Robson (ed.). Soil acidity and plant growth. Marrickville, Academic Press.

HELYAR, K.R., CREGAN, P.D. \& GODYN, D.L., 1990. Soil acidity in New South Wales - Current $\mathrm{pH}$ values and estimates of acidification rates. Aust. J. Soil Res. 28, 523-537.

HILL, P.A., 2003. Using geographic information systems (GISs) in soil acidification risk assessments. In: Rengel, Z. (ed.). Handbook of soil acidity. Marcel Dekker Inc., New York.

HOYT, P.B. \& HENNING, A.M.F., 1982. Soil acidification by fertilizer and longevity of lime applications in the Peace river region. Can. J. Soil Sci. 62, 155-163.

JUO, A.S.R., 1977. Soluble and exchangeable aluminium in Utisols and Alfisols in West Africa. Comm. Soil Sci. Plant Anal. 8, 1735.

MATZNER, E. \& MEIWES, K.J., 1994. Long-term development of element fluxes with bulk precipitation and through fall in two German forests. J. Environ. Qual. 23, 162-166.

McLEAN, E.O., ECKERT, D.J., REDDY, G.Y. \& TRIERWEILER, J.F., 1978. An improved SMP soil requirement method incorporating double-buffer and quick test features. J. Soil Sci. Soc. Am. 42, 311-316.

PONIZOVSKIY, A.A. \& PAMPURA, T.V., 1993. Use of Potentiometric titration to describe the buffer capacity of soils. Eurasian Soil Sci. 25, 106-115.

RIDLEY, A.M., HELYAR, K.R. \& SLATTERY, W.J., 1990. Soil 
acidification under subterranean clover (Trifolium subterraneum L.) pasture in northern-eastern Victoria. Austr. J. Experim. Agric. 30, 195-201.

SINGH, B., ODEH, I.O.A. \& McBRATNEY, A.B, 2003. Acid buffering capacity and potential acidification of cotton soils in northern New South Wales. Aust. J. Soil.Res. 41, 875-888.

SOIL CLASSIFICATION WORKING GROUP, 1991. Soil classification - A Taxonomic System for South Africa. Soil and Irrigation Research Institute, Department of Agricultural Development, Pretoria, SA.

STEINKE, M.F., BEUKES, D.J. \& BUHMANN, C., 2004. The relationship between acid buffer capacity and properties of selected soils in a high rainfall area of South Africa, p. 134-136. In: H. Matsumoto, M. Nanzyo, K. Inubushi, Y. Yamamoto, H. Koyama, M. Saigusa, M. Osaki, \& K. Sakurai (eds.). Proceedings of the 6th International Symposium on Plant-Soil Interaction under Low $\mathrm{pH}, 1-5$ August, Sendai, Japan.

SUMNER, M.E. \& NOBLE, A.D., 2003. Soil acidification: The world story. In: Rengel, Z. (ed.). Handbook of soil acidity. Marcel Dekker Inc., New York.

THE NON-AFFILIATED SOIL ANALYSIS WORK COMMITTEE, 1990. Handbook of Standard Soil Testing Methods for Advisory Purposes. Soil Science Society of South Africa, Pretoria. 